\title{
Cognitive-Pragmatic Interpretation of Linguistic Personality (on the example of market-economic terminology)
}

\author{
Sofiya N. Semenova ${ }^{1}$, Lyudmila G. Aksyutenkova ${ }^{2}$ \\ ${ }^{1,2}$ Kuban State University \\ Stavropolskaya st., 149, Krasnodar, Russian Federation, 350040 \\ ${ }^{1}$ sofiya.semenova75@yandex.ru
}

\begin{abstract}
The article presents a conceptual apparatus of conceptualization on the example of economic cognitive sphere. The relevance of this work can be considered from the point of view of "language of the market" study as an accumulative sphere of fixation of "market-economic" surrounding reality, and a cognitive-pragmatic aspect of human consciousness' development. The aim was to evaluate the language of market economy from cognitive-derivational position as well as problems connected with the usage of borrowed foreign words. The authors solved the tasks: 1) analyzed and interpreted "language of the market" special vocabulary in English and Russian; 2) understood the scientific and the professional picture of the world through the "economic" language; 3) identified the specific expression of external and internal state of its participants; 4) found out the borrowed foreign words; 5) described the collected information. During the study of the material the authors used: 1) the component analysis method; 2) the continuous sampling method; 3) the analysis of terminological definitions; 4) the classification method. The researchers analyzed the concept, which was the main result and means of linguistic conceptualization of the world and the economic term as a result and means of conceptualization of the economic picture of the world. The main parameters of economic cognitive derivational system and borrowed foreign words spheres were described. A detailed analysis of terminological phrases allowed identifying the most common structural types of functioning in the economic cognitive sphere of composite economic terms and borrowed foreign words. It can be concluded that the study of the market economy language makes it possible to regard its evolution as a result of social, creative, spiritual activity of economic branch and science.
\end{abstract}

Key words: terminology, borrowed foreign words, subject area "language of the market", cognitive, conceptualization, vocabulary, derivation, economic picture of the world

\section{Article history:}

Received: 20.06 .2020

Accepted:15.07.2020

\section{For citation:}

Semenova, S.N. \& Aksyutenkova, L.G. (2020). Cognitive-Pragmatic Interpretation of Linguistic Personality (on the example of market-economic terminology). RUDN Journal of Language Studies, Semiotics and Semantics, 11 (4), 760-774. doi: 10.22363/2313-2299-2020-11-4-760-774

(C) Семенова С.Н., Аксютенкова Л.Г., 2020

This work is licensed under a Creative Commons Attribution 4.0 International License https://creativecommons.org/licenses/by/4.0/ 


\title{
Когнитивно-прагматическая интерпретация языковой личности (на примере рыночно-экономической терминологии)
}

\author{
С.Н. Семенова ${ }^{1}$, Л.Г. Аксютенкова ${ }^{2}$ \\ ${ }_{1,2}$ Кубанский государственный университет \\ ул. Ставропольская, 149, Краснодар, Российская Федерачия, 350040 \\ ${ }^{1}$ sofiya.semenova75@yandex.ru
}

В работе представлен комплексный анализ концептуализации на примере экономической когнитивной сферы. Актуальность данной работы можно рассматривать с точки зрения изучения «языка рынка» в виде аккумулятивной сферы фиксации, окружающей «рыночно-экономической» действительности, и когнитивно-прагматического аспекта развития человеческого сознания. Цель исследования - продолжение изучения языка рыночной экономики как с когнитивно-деривационной позиции, так и проблем, связанных с использованием заимствованных иностранных слов. Решены следующие задачи: 1) анализирован и интерпретирован массив специальной лексики «языка рынка» на английском и русском языках; 2) объяснена научно-профессиональная картина мира через «экономический» язык; 3) обозначено специфическое выражение внешнего и внутреннего состояния его носителей; 4) выделены заимствованные иностранные слова; 5) описана собранная информация. В исследовании материала авторы использовали: 1) метод компонентного анализа; 2) метод сплошной выборки; 3) анализ терминологических дефиниций; 4) классификационный метод. В работе анализирован концепт, являющийся основным результатом и средством языковой концептуализации мира и экономический термин как результат и средство концептуализации экономической картины мира. Представлены и описаны основные параметры деривационной системы и заимствования иностранных слов экономической когнитивной сферы. Согласно проведенному исследованию сделан вывод, что изучение языка рыночной экономики дает возможность расценивать ее эволюцию как результат социальной, креативной, духовной деятельности субъекта экономической сферы и науки.

Ключевые слова: терминология, заимствование иностранных слов, предметная область «язык рынка», когнитивный, концептуализация, вокабуляр, деривация, экономическая картина мира

\section{История статьи:}

Дата поступления: 20.06.2020

Дата приема в печать: 15.07.2020

\section{Для цитирования:}

Семенова С.Н., Аксютенкова Л.Г. Когнитивно-прагматическая интерпретация языковой личности (на примере рыночно-экономической терминологии) // Вестник Российского университета дружбы народов. Серия: Теория языка. Семиотика. Семантика, 2020. Т. 11. no 4. C. $760-774$. doi: 10.22363/2313-2299-2020-11-4-760-774

\section{Introduction}

The interpretation of science language as a unique way of scientific consciousness being traces the relationship of the personal factor in the language 
with the image of science subject. Many researchers working on this problem note that a deeper and broader language understanding is more needed than the perception of only signs' system. "Language is an intermediary means not only between the speaker and the listener, but also between a person and the world. Any language is constituted in the following triangle: Man - Reality - Real time." [1. P. 580].

The relevance of this work can be considered from the point of view of "language of the market" study as an accumulative sphere of fixation of "marketeconomic" surrounding reality, and a cognitive-pragmatic aspect of human consciousness' development.

The main aim was to evaluate the language of market economy from cognitive-derivational position as well as problems connected with the usage of borrowed foreign words.

In linguistic science, the period of the past fifty years was marked by a special interest in professional and business communication problems. The promotion of "language personality" phenomenon in the language theory indicates an increasing attention to a person, to his cognitive-pragmatic and creativecommunicative activities, to his personal picture of the world. This viewpoint receives strong scientific support by Yu.N. Karaulov's position, who considered the conceptual field of "linguistic personality" term in three denotations:

1) a linguistic personality is personified for us as the owner of a certain national mentally-linguistic complex;

2) it is an identity of a philologist-specialist;

3 ) it is a scientific paradigm "man and language" [2. P. 5].

Thanks to the linguistic ideas of contemporary scientists, working in the same directions [3; 4], our observations of the phenomenon of speech personality assume that the essences of the phenomenon are paradigmatic, systematic, naturally manifesting in functioning, the ultimate idea of which we can explain as the communication, and not in common, but here and now. This judgment is supplemented by an additional link in the paradigm of real communication: a communicative person - a specific participant in a specific communicative act.

\section{Linguistic Personality}

\subsection{The analysis of scientific literature and the "language of the market"}

With the transition of Russian economy from the planned stage to the market one, there have been some changes and discussions in the economic, political and social spheres of society. As a consequence, the economic meta-language has also undergone significant changes, as there was an urgent need for a huge number of people to learn new scientific paradigms and communicate in a new language the "language of the market". After all being a meta-language of the market economy science, the "language of the market" represents the professional and communicative aspect of the sociolect. 
The most important conceptual parts of scientific knowledge are implemented by a system of specific term units that form the terminological system "Market economy" or "Language of the market".

The actual problem of the study of the "language of the market" was determined both as an accumulative sphere of fixation and reflection of the surrounding "market-economic" reality and as a cognitive-linguistic aspect of the evolution of human consciousness at the beginning of the twenty-first century. Economic, scientific and professionally-oriented literature is a great help in texts studying with a specific sphere of terminology of the "language of the market" as the conceptual-epistemological sphere for specific purposes.

We can follow L.Yu. Buyanova in assuming that the "language of the market" is rapidly developing in the result of continuous changes in society's social life [5. P. 19]. As the practice showed it happened in such a way.

\subsection{External and internal connection of linguistic interpretation of a linguistic personality}

Now we shall touch upon the issue concerning the understanding of the "language of the market". Here it can be indicated its great importance in the context of studying the evolution factor of language. The term system of the "language of the market" is its material basis. A person (using certain termforming means, models and parameters) creates the necessary market and economic terms for expressing his thoughts, representing ideas, for the exchange of scientific and professional information between members of a certain society. It can be assumed that the linguistic explication of economic market relations occurs due to term-making, immediately reflected in professional and communicative activity.

So, it is important to analyze and to interpret the special vocabulary of the "language of the market" taking into account the principle of anthropocentrism, which allows us to understand the scientific and professional picture of the world through the "language of the market" in order to designate a specific expression of the external and internal state of its participants.

Now-a-days the Market Economy as a science and a specific sphere of activity is to attract an increasing number of specialists. The Economy as a science is quickly socialized. More and more people are employed in the economic sphere. The number of denotations correlated with specific market and economic concepts constantly grows [6. P. 156; 7. P. 15]. In our opinion, it is interesting to analyze and to interpret the special vocabulary. We consider it appropriate to emphasize the economic value of the term as one of the most important mental-cognitive means of conceptualization reality. So in the present work we try to describe the conceptual framework of the conceptualization in the language theory. Problems of terminology are proposed in the scientific works on the language theory by such researchers as: G.P. Melnikov [8], L.Yu. Buyanova [9] and others $[10 ; 11 ; 12]$. 
A significant number of interpretations of the term (more than 2000) indicates the complexity of this concept's development. To know and to understand a scientific concept means to master its content, to base on its distinctive features in dictionary definitions.

According to many investigators' analysis on this problem, we consider it appropriate to note that "good" term units should be "separated" from polysemy, expressiveness and, consequently, from semantic processes of ordinary nonterminological words of the Russian literary language [13; 14]. However, it should be underlined that there is no connection between the term and the ordinary word. As our observations show, in language and logic there is an opposition of the concept "term" - "non-term". Economic terminology is not an exception in a constant functional and semantic exchange between terms and ordinary words.

\section{Conceptual Apparatus of Conceptualization in the Language Theory}

\subsection{General characteristics of the conceptual apparatus of conceptualization}

The conceptualization of the world is a complex linguistic process, which has not yet found its unambiguous solution in the language theory. Currently, the priority in linguistic science is the identification and interpretation of cognitive mechanisms that prevail in the original form in various types of cognitive processes. They (cognitive mechanisms) are fundamentally important for the study and understanding of human consciousness.

The "conceptualization" term is used in various scientific fields: Linguistics, Logic, Philosophy, Economics, etc. This process is a certain form of scientific knowledge structuring. It is strategically important to define it and to establish correlation with related concepts, such as: concept, term, non-term. In the language theory the "conceptualization" term is treated very ambiguously. As a rule, it is understood as the process of knowledge systematization and structuring accumulated in the process of mankind evolution. We are close to S.G. Vorkachev's theory, who believes that the conceptualization is a set of semantic representation methods of a lexical unit content that is various in different cultures [15]. It is significant that changes in the socio-political and socio-economic life of society cause differences in language and speech.

\subsection{Terminological conceptualization of economic cognitive sphere}

The second half of the twentieth century has witnessed the flourishing of the terminological conceptualization of the economic cognitive sphere. The number of borrowings of the economic terminological system in Russian is growing. The concepts of "Market", "Finance", "Credit", "Insurance", "Money" and "Exchange" are becoming dominant in the Russian economic cognitive sphere. 
Thus, the described role of the language is very important both in the intercorrelation processes of language and society and in representation of the economic picture of the world in the conditions of Russian and world economy further modernization.

Developing the conceptualization theory, we think that simultaneously with the evolution of concepts' semantics, it is also interesting to study the derivational processes and borrowed foreign words taking place in concepts' formation.

In our research the received results proved that an objective reality is conceptualized step by step in the following way:

1) the subject of the reality surrounding us is objectified. It is filled with a certain meaning leading to the corresponding concept appearance in human brain;

2) the volume of the perceived information increases. As a result, the number of concepts multiplies and develops into specific conceptual structures and systems;

3) the comprehension of the information in the conceptual form leads either to the verbalization of concepts, or to rethinking and generation of new notions.

Based on the chosen scientific perspective we analyze the concept and the specificity of language material as one of the basic concepts and terms. Following V.I. Karasik's point of view, we believe: "conceptualization of reality is carried out as a designation, expression and description. ... and the description of the concept is a special research procedure for the interpretation of the meaning of the nearest designations" [16].

The theory of information is an important aspect of conceptualization's and concepts' study in the language theory. Conceptualization can also be seen as the way in which the reality is verbalized. Consequently, the same surrounding reality is experienced differently by various people. It can lead to the change of the semantic, lexical and grammatical systems of languages.

\section{Terms in Economic Sphere}

\subsection{Derivational system of economic cognitive sphere}

Due to the above said we suppose that it is important to analyze, firstly, the derivational system of the economic cognitive sphere and, secondly, borrowed foreign words. So, to describe the main parameters of the derivational system of the economic cognitive sphere, we have subjected to derivational analysis of about 10,000 terms taken from economic terminological literature (in English and Russian). The importance and evolution of the theory of derivation also contributed to the construction of various derivational models. A detailed analysis of terminological phrases allowed us to identify the most common structural types of composite economic terms. The received results of our investigation are given in the following table. 
Table 1 / Таблица 1

Structure of models participating in the formation of terms / Структура моделей, участвующих в формировании терминов

\begin{tabular}{|l|l|l|l|}
\hline \multirow{2}{*}{$N o$} & $\begin{array}{l}\text { Term structure / } \\
\text { Структура термина }\end{array}$ & $\begin{array}{l}\text { Моdel / } \\
\text { Модель }\end{array}$ & $\begin{array}{l}\text { Example / } \\
\text { Пример }\end{array}$ \\
\hline \multirow{3}{*}{1.} & \multirow{2}{*}{ Two-element } & Adj + N & non-cumulative dividend \\
\cline { 3 - 4 } & & $\mathrm{P}+\mathrm{N}$ & funded loan \\
\hline 2. & Three-element & Adj + Adj $+\mathrm{N}$ & private discount rate \\
\hline 3 & \multirow{3}{*}{ Four-element } & $\mathrm{Adj}+\mathrm{N}+\mathrm{Adj}+\mathrm{N}$ & gold content of the monetary unit \\
\cline { 3 - 4 } & $\mathrm{N}+\mathrm{Adj}+\mathrm{Adj}+\mathrm{N}$ & gross national product deficit \\
\cline { 3 - 4 } & $\mathrm{N}+\mathrm{N}+\mathrm{N}+\mathrm{N}$ & product range plan cycle \\
\cline { 3 - 4 } & $\mathrm{N}+\mathrm{P}+\mathrm{Adj}+\mathrm{N}$ & the law of increasing time costs \\
\cline { 3 - 4 } & $\mathrm{N}+\mathrm{Adj}+\mathrm{P}+\mathrm{N}$ & index of leading long-term indicators \\
\hline
\end{tabular}

The number of compound terms formed by Participle + Noun $(\mathrm{P}+\mathrm{N})$ models are quantitatively much less common than the structural type of: Adjective + Noun $(\operatorname{Adj}+N)$.

Among the three-element terminated phrases, the structural type is more often used in the processes of derivation: Adjective + Adjective $+\operatorname{Noun}(\operatorname{Adj}+\operatorname{Adj}+N)$.

When considering the four-element term combinations, it turned out that the most frequent is the structural type: Adjective + Noun + Adjective + Noun $($ Adj + $\mathrm{N}+\operatorname{Adj}+\mathrm{N})$.

Thus, increasing the length of the phrase, the "Creator" of the economic term seeks to clarify the concept. In the process of further development of economic terminology, terms may be transformed in the meaning of the concept without the change. Among the main peculiar features of the studied terminology there are not a great number of term-phrases in which one of the elements is presented by an adjective-colorism [17]. To follow and prove that point of view we suggest our opinion of that idea in the following material, indicated in Tb. 2 and Fig. 1.

According to the information of the Tb. 2 we can conclude that the "universal color triad" of the "language of market" consists of the following colors: black, green and white. These data show that the economic term system has a "color". On Fig. 1 each segment displays the number of examples found by us in the process of our research (the examples are on the Tb. 2). The derivation defines the term-forming potential of the language as a terminological conceptualization way of the economic cognitive sphere.

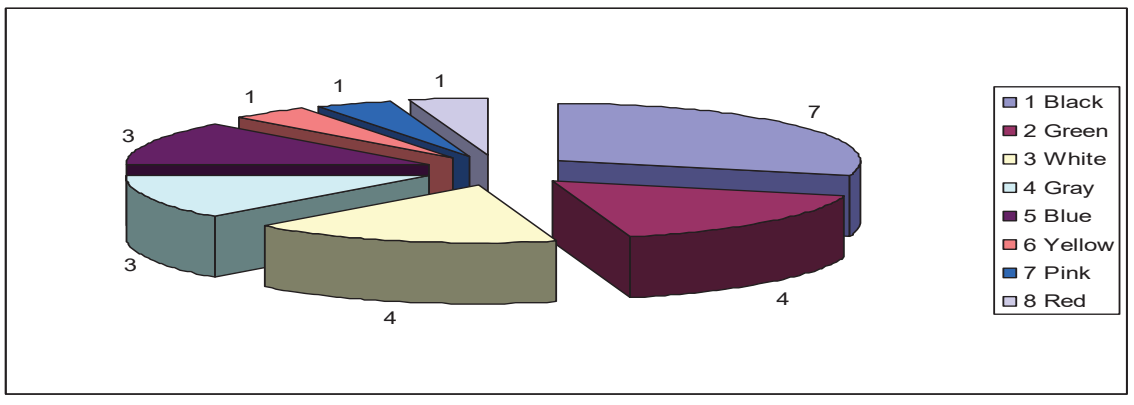

Fig. 1. Quantitative ratios of derived terms with adjective-colorism / Рис. 1. Количественные соотношения производных терминов с прилагательным-колоризмом 
Table 2 / Таблица 2

\section{Quantitative ratios of derived terms with adjective-colorism / Количественные соотношения производных терминов с прилагательным-колоризмом}

\begin{tabular}{|c|c|c|c|}
\hline № & Color / Цвет & Examples / Примеры & $\begin{array}{l}\text { Quantity of derived terms / } \\
\text { Количество производных терминов }\end{array}$ \\
\hline \multirow[t]{7}{*}{1.} & \multirow{7}{*}{ Black } & "black market" & \multirow[t]{7}{*}{ 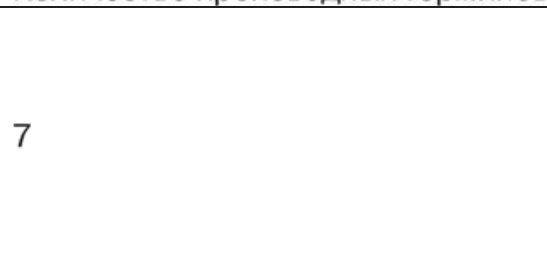 } \\
\hline & & "black cash" & \\
\hline & & "black Friday" & \\
\hline & & "black return" & \\
\hline & & "black door" & \\
\hline & & "black capitalism" & \\
\hline & & "black broker" & \\
\hline \multirow[t]{4}{*}{2.} & \multirow{4}{*}{ Green } & "green card" & \multirow{4}{*}{4} \\
\hline & & "green revolution" & \\
\hline & & "green money" & \\
\hline & & "green blackmail" & \\
\hline \multirow[t]{4}{*}{3.} & \multirow{4}{*}{ White } & "white knight" & \multirow{4}{*}{4} \\
\hline & & "white collar" & \\
\hline & & "white elephant" & \\
\hline & & "white noise" & \\
\hline \multirow[t]{3}{*}{4.} & \multirow{3}{*}{ Gray } & "gray wave" & \multirow{3}{*}{3} \\
\hline & & "gray collar" & \\
\hline & & "gray market" & \\
\hline \multirow[t]{3}{*}{5.} & \multirow{3}{*}{ Blue } & the law of "blue skies" & \multirow{3}{*}{3} \\
\hline & & "blue collars" & \\
\hline & & "blue spines" & \\
\hline 6. & Yellow & "yellow commitment" & 1 \\
\hline 7. & Pink & emission of "pink form" & 1 \\
\hline 8. & Red & the price is "red" & 1 \\
\hline
\end{tabular}

\subsection{Borrowed foreign words used in economic cognitive sphere in English and Russian}

In continuation of the above mentioned data and results of the present paper we think that it is necessary to show the following information also received in the process of studying of the economical sphere. We put the borrowed foreign words (terms) into 4 groups by their peculiar features as: the part of speech, the examples, the quantity and the percentage ratios in the Tb. 3 .

Table 3 / Таблица 3

\section{Distribution of borrowed foreign words (terms) / \\ Распределение заимствованных иностранных слов (терминов)}

\begin{tabular}{|c|l|l|l|l|}
\hline № & $\begin{array}{l}\text { Part of } \\
\text { speech / } \\
\text { Часть речи }\end{array}$ & Examples / Примеры & $\begin{array}{l}\text { Quantity / } \\
\text { Количество }\end{array}$ & $\%$ \\
\hline 1. & Noun & $\begin{array}{l}\text { Accuracy (аккуратность), activity (активность), } \\
\text { adequacy (адєкватность), agency (агентство), } \\
\text { alimentation (поддержка), acсерtance (акцент), } \\
\text { alliance (альянс), analysis (анализ), аррагаtus } \\
\text { (аппарат), азsignation (ассигнование), } \\
\text { assignment (ассиговани), assortment } \\
\text { (ассортимент), bank (банк), banker (банкир), }\end{array}$ & 109 & 68,6 \\
\hline
\end{tabular}




\begin{tabular}{|c|c|c|c|c|}
\hline № & $\begin{array}{l}\text { Part of } \\
\text { speech / } \\
\text { Часть речи }\end{array}$ & Examples / Примеры & $\begin{array}{l}\text { Quantity / } \\
\text { Количество }\end{array}$ & $\%$ \\
\hline & & 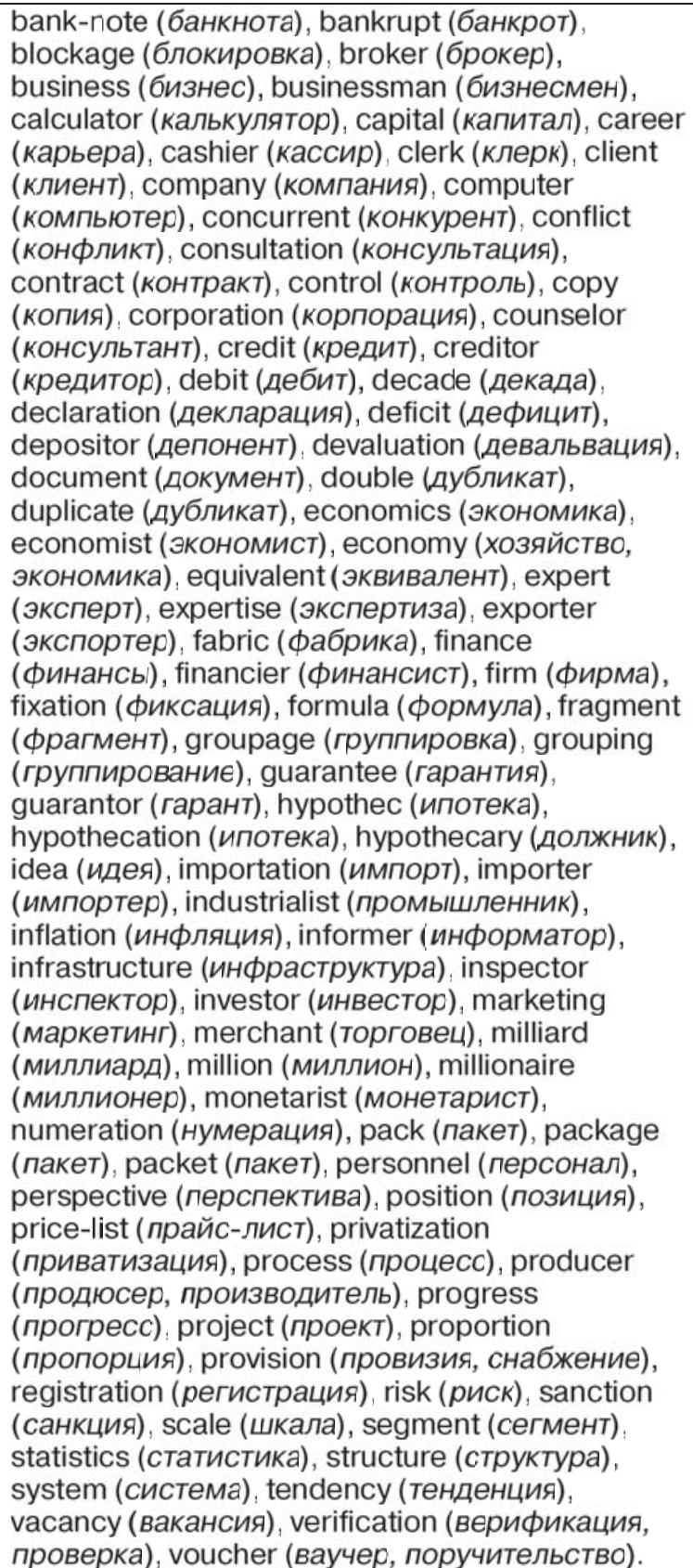 & & \\
\hline 2. & Adjective & $\begin{array}{l}\text { Accepted (общепринятый), bank-book } \\
\text { (банковская книжка), banking (банковское } \\
\text { дело), budgetary (бюджетный), central } \\
\text { (центральный), confidential } \\
\text { (конфиденциальный), corporate } \\
\text { (корпоративный), credit card (кредитная } \\
\text { карточка), declarative (декларативный), } \\
\text { economic (экономический), economical }\end{array}$ & 33 & 20,7 \\
\hline
\end{tabular}




\begin{tabular}{|c|c|c|c|c|}
\hline № & $\begin{array}{l}\text { Part of } \\
\text { speech / } \\
\text { Часть речи }\end{array}$ & Examples / Примеры & $\begin{array}{l}\text { Quantity/ } \\
\text { Количество }\end{array}$ & $\%$ \\
\hline & & $\begin{array}{l}\text { (экономный), effective (эффективный), effectual } \\
\text { (эффективный), financial (финансовый), formal } \\
\text { (формальный), functional (функциональный), } \\
\text { individual (индивидуальный), informed } \\
\text { (информированный), investment bank } \\
\text { (инвестиционный банк), irrational } \\
\text { (иррациональный), monetary (монетарный), } \\
\text { nominal (номинал), positive (позитивный), private } \\
\text { (приватный), productive (продуктивный), } \\
\text { progressive (прогрессивный), rational } \\
\text { (рациональный), relevant (релевантный), special } \\
\text { (специальный), specific (специальный), } \\
\text { structural (структурный), vacant (вакантный), } \\
\text { value (валюта), valuta (валюта). }\end{array}$ & & \\
\hline 3. & Verb & $\begin{array}{l}\text { To accelerate (ускоряться), to accommodate } \\
\text { (приспосабливать), to accumulate } \\
\text { (аккумулировать), to administer (управлять), } \\
\text { to agitate (агитировать), to block (блокировать), } \\
\text { to calculate (калькулировать, считать), } \\
\text { to devaluate (обесценивать), to есоnomize } \\
\text { (эксномить), to expertize (проводить } \\
\text { экспертизу), to formulate (формулировать), } \\
\text { to invest (инвестировать), to recommend } \\
\text { (рекомендовать), to reproduce (репродуцировать) }\end{array}$ & 14 & 8,8 \\
\hline 4. & Adverb & $\begin{array}{l}\text { Periodically (периодически), personally } \\
\text { (персонально), regularly (регулярно) }\end{array}$ & 3 & 1,9 \\
\hline \multicolumn{3}{|r|}{ 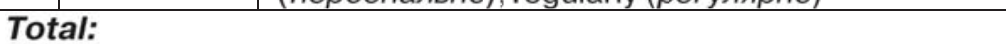 } & 159 & 100 \\
\hline
\end{tabular}

So due to the Tb. 3 and diagram (Fig. 2) we can see that the most frequent used part of speech was "Noun" (109 terms $(68,6 \%))$ and the least - "Adverb" (3 terms $(1,9 \%))$.

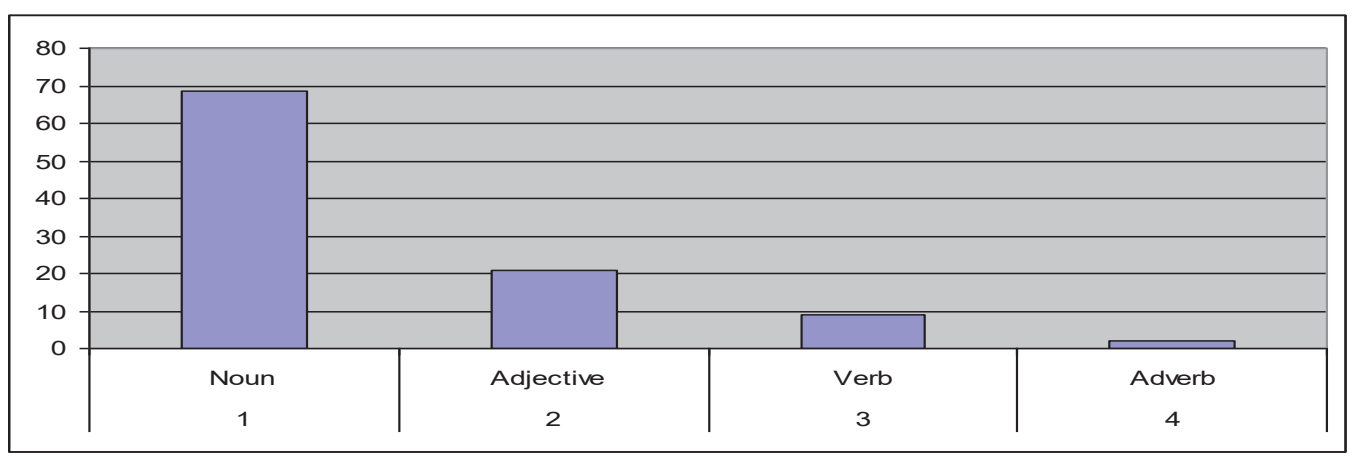

Fig. 2. Quantitative ratios of terms by their part of speech /

Рис. 2. Количественные соотношения терминов по их части речи

In the Noun column of the Tb. 3 we defined out such personalities (people) involved in the economic sphere as:

Banker (банкир), broker (брокер), businessman (бизнесмен), cashier (кассир), clerk (клерк), client (клиент), concurrent (конкурент), counselor (консультант), creditor (кредитор), economist (экономист), expert (эксперт), 
exporter (экспортер), financier (финансист), hypothecary (должник), importer (импортер), industrialist (промьиленник), informer (информатор), inspector (инспектор), investor (инвестор), merchant (торговеч), millionaire (миллионер), monetarist (монетарист), personnel (персонал), producer (продюсер, производитель).

The next step of our investigation was to find synonyms and to classify them by their part of speech:

1. Nouns: assignation (ассигнование) — assignment (ассигнование), double (дубликат) — duplicate (дубликат), groupage (группировка) — grouping (группирование), hypothec (ипотека) - hypothecation (ипотека), pack (пакет) — package $($ пакет) — packet $($ пакет), value (валюта) — valuta (валюта).

2. Adjective: effective (эффективныли) — effectual (эффективный), special (специиальный) - specific (спецчиальный).

As follows from the above written results and materials, the data of (the derived terms with adjective-colorism and the borrowed foreign words) were presented in the Excel table, where they were counted on the basis of quantitative ratios. Based on those data, the diagrams (Fig. 1, Fig. 2) were constructed in the same Excel programme. When we finished working in that programme, the tables (Tb. 2, Tb. 3) and diagrams (Fig. 1, Fig. 2) were copied in the text of the present article in Word programme, where their contents were illustrated and described.

\subsection{Productivity of suffixes in borrowed foreign words}

As it is widely known among scientists in language studies, affix system of English is presented by a set of suffixes and prefixes. But in the present paper only suffixes were studied and analyzed. So, all suffixes had different productivity. To simplify the understanding of the received information on the borrowed foreign words we decided to put it in the brackets after each suffix simaltenuously with examples, classified by their part of speech. It has the following structure and content:

1. Nouns: -ity (1): activity (активность); -acy (2): accuracy (аккуратность), adequасу (адекватность); -tion (16): alimentation (поддержка), assignation (ассигнование), consultation (консультация), corporation (корпорация), fixation (фиксация), declaration (декларация), devaluation (девальвация), hypothecation (ипотека), inflation (инфляция), importation (импорт), position (позиция), proportion (пропорция), privatization (приватизация), registration (регистрация), sanction (санкция), verification (верификация, проверка); -ance (2): acceptance (акцент), alliance (альянс); -ist (2): economist (экономист), industrialist (промыииленник); -ure (1): infrastructure (инфраструктура); -age (3): blockage (блокировка), groupage (группировка), package (пакет); -ment (2): assignment (ассигнование), assortment (ассортимент); -ing (2): grouping (группирование), marketing (маркетинг); -ive (1): perspective (перспектива); -er (7): banker 
(банкир), broker (брокер), informer (информатор), producer (продюсер, производитель), exporter (экспортер), financier (финансист), importer (импортер); -or (3): inspector (инспектор), investor (инвестор), calculator (калькулятор).

2. Adjective: -ed (2): accepted (общепринятый), informed (информированный); -ing (1): banking (банковское дело); -ary (2): budgetary (бюджетнылй), monetary (монетарный); -al (11): central (центральный), confidential (конфиденциальный), economical (экономный), effectual (эффрективный), financial (финансовыги), formal (формальный), functional (функциональный), individual (индивидуальный), irrational (иррациональнызй), rational (рациональный), structural (структурнылй); -ive (5): declarative (декларативнылй), effective (эффективныцй), positive (позитивный), productive (продуктивный), progressive (прогрессивный).

3. Adverb: -ly (3): periodically (периодически), personally (персонально), regularly (регулярно).

On the results of the described analysis of above given suffixes with the examples of borrowed foreign words, we constructed $\mathrm{Tb}$. 4 , demonstrating the following inference:

Table 4 / Таблица 4

Suffix formation in borrowed foreign words / Суффиксальное образование в заимствованных иностранных словах

\begin{tabular}{|r|l|l|l|}
\hline № & Suffix / Суффикс & Quantity / Количество & $\%$ \\
\hline 1. & - acy & 2 & 3 \\
\hline 2. & -age & 3 & 4,54 \\
\hline 3. & -al & 11 & 16,8 \\
\hline 4. & -ance & 2 & 3 \\
\hline 5. & -ary & 2 & 3 \\
\hline 6. & -ed & 2 & 3 \\
\hline 7. & -er & 7 & 10,7 \\
\hline 8. & -ing & 3 & 4,54 \\
\hline 9. & -ist & 2 & 3 \\
\hline 10. & -ity & 1 & 1,5 \\
\hline 11. & -ive & 1 & 1,5 \\
\hline 12. & -ive & 5 & 7,6 \\
\hline 13. & -ly & 3 & 4,54 \\
\hline 14. & -ment & 2 & 3 \\
\hline 15. & -or & 3 & 4,54 \\
\hline 16. & -tion & 16 & 24,24 \\
\hline 17. & -ure & 1 & 1,5 \\
\hline & & 66 & $\mathbf{1 0 0}$ \\
\hline
\end{tabular}


In that way all suffixes had different productivity due to data of the $\mathrm{Tb} .4$. We revealed that the most productive suffixes in borrowed foreign words were: -tion (16 terms $(24,24 \%))$ and -al $(11$ terms $(16,8 \%))$, the least productive suffixes were only in (1 term $(1,5 \%))$ : -ity, -ive, -ure.

By the help of the computer programmes it was possible to conduct the research, to write the interpretation and the detailed analysis of the tables and the diagrams in revealing the main characteristics of the economic terms.

\section{Conclusion}

So we offer our vision of the linguistic phenomenon, considering the conceptualization as a method of conceptology, which has a dual structure of method and process, taking into account the existing definitions

Further investigations in the economic sphere will allow understanding of importance of modern society's activity.

Summing all up we came to the matter that the conceptualization is a set of specific actions for the study and description of human cognitive activity, consisting in the perception and interpretation of information on the surrounding reality and leading to the concepts' and conceptual systems' formations.

In future it will be perspective to put the materials, results and conclusions of this work into the practice and theory of the language.

\section{References}

1. Yurchenko, V.S. (1995). Some features of syntactic science of the XX century and prospects of its development In Linguistics at the end of the XX century: Results and prospects, 2. Moscow. pp. 580-581. (In Russ.).

2. Karaulov, Yu.N. (1989). Preface. Russian language personality and the tasks of its study. Moscow: Nauka. pp. 3-8. (In Russ.).

3. Krasina, E.A. \& Gabballa, M.H. (2018). Switching codes: current state. RUDN Journal of Language Studies, Semiotics and Semantics, 9 (2), 403-415. doi: 10.22363/2313-22992018-9-2-403-415. (In Russ.).

4. Divjak, D., Levshina, N. \& Klavan, J. (2016). Cognitive Linguistics: Looking Back, Looking Forward. Cognitive Linguistucs, 27 (4), 447-463. doi: 10.1515/cog-2016-0095.

5. Buyanova, L.Yu. (2018). Terminology verbalization category of the subject of financialeconomic activity: derivation aspect. Bulletin of the Adyghe State University. Ser.: "Philology and Arts", 2 (217), 17-21. (In Russ.).

6. Semenova, S.N. (2015). Characteristics of discourse term systems in the subject area "Mountain ecosystems". Philological Sciences. Questions of Theory and Practice, 7 (2), 155-159. (In Russ.).

7. Aksyutenkova, L.G. (2011). Conceptual framework of the conceptualization in language theory: General characteristics. Bulletin of the Stavropol State University, 76, 13-19. (In Russ.).

8. Melnikov, G.P. (1991). Fundamentals of terminology: Studies. Benefits. Moscow: Peoples' Friendship University publ. (In Russ.).

9. Buyanova, L.Yu. (1996). Terminological derivation in modern Russian language (metalanguage aspect). Krasnodar: Krasnodar book publ. house. (In Russ.).

10. Zvegintsev, V.A. (1967). Theoretical and applied linguistics. Moscow: Prosveschenie publ. (In Russ.). 
11. Aksyutenkova, L.G. (2010). Derivation, as a way of conceptualizing of economic terminological cognitive sphere. Bulletin of the Adyghe State University. Ser.: "Philology and Arts", 4, 65-69. (In Russ.).

12. Zhandarova, A.V., Semenova, S.N. \& Aksyutenkova, L.G. (2018). Modern problems of cognitive activity in the subject area "Entrepreneurship and Business". Krasnodar: Ekoinvest. (In Russ.).

13. Mak, W.M., Tribushinina, E. \& Andreiushina, E. (2013). Semantics of Connectives Guides Referential Expectations in Discourse: an Eye-Tracking Study of Dutch and Russian. Discourse Processes, 50(8), 557-576. doi: 10.1080/0163853x.2013.841075.

14. Baranov, A.G. (1999). Cognitive formalisms of textual activities. Bulletin of the Pyatigorsk Linguistic University, 2, 34 -37. (In Russ.).

15. Vorkachev, S.G. (2002). Methodological bases of linguoconceptology In Aspects of metacommunicative activity, vol. 3. Voronezh. pp. 79-96. (In Russ.).

16. Karasik, V.I. (2002). Language circle: personality, concept, discourse. Volgograd: Peremena publ. (In Russ.).

17. Butler, B. \& Isaac, A. (2000). Finance: an Explanatory dictionary. Moscow: Infra-M Publishing house "Ves' Mir" publ. (In Russ.).

\section{Библиографический список}

1. Юрченко В.С. Некоторые особенности синтаксической науки XX века и перспективы ее развития // Лингвистика на исходе XX века: Итоги и перспективы: Тез. международ. конфер. М., 1995. T. II. С. 580-581.

2. Караулов Ю.Н. Предисловие. Русская языковая личность и задачи ее изучения // Язык и личность. М.: Наука, 1989. С. 3-8.

3. Красина Е.А., Жаббалла М.Х. Переключение кодов: современное состояние // Вестник Российского университета дружбы народов. Серия: Теория языка. Семиотика. Семантика. 2018. T. 9. nо 2. С. 403 - 415. doi: 10.22363/2313-2299-2018-9-2-403-415.

4. Divjak D., Levshina N., Klavan J. Cognitive Linguistics: Looking Back, Looking Forward // Cognitive Linguistucs. Germany: Mourton de Gruyter, 2016. Vol. 27. no 4. Pp. 447—463. doi: 10.1515/cog-2016-0095.

5. Буянова Л.Ю. Терминологическая вербализация категории субъекта финансовоэкономической деятельности: деривационный аспект // Вестник Адыгейского госуниверситета. Серия «Филология и искусствоведение». Майкоп: Адыгейский государственный университет, 2018. Вып. 2 (217). С. 17-21.

6. Семенова С.Н. Характеристики терминосистем дискурса в предметной области «Горные экосистемы» // Филологические науки. Вопросы теории и практики. 2015. nо 7. Ч. 2. C. $155-159$.

7. Аксютенкова Л.Г. Понятийный аппарат концептуализации в теории языка: общая характеристика // Вестник Ставропольского государственного университета. Ставрополь: Ставропольский государственный университет, 2011. Вып. 76. С. 13-19.

8. Мельников Г.П. Основы терминоведения: Учеб. пособие. М.: Изд-во ун-та дружбы народов, 1991.

9. Буянова Л.Ю. Терминологическая деривация в современном русском языке (метаязыковой аспект). Краснодар: Краснодарское книжное издательство, 1996.

10. Звегинщев B.A. Теоретическая и прикладная лингвистика. М.: Просвещение, 1967.

11. Аксютенкова Л.Г. Деривация как способ терминологической концептуализации экономической когнитивной сферы // Вестник Адыгейского государственного университета. Серия «Филология и искусствоведение». Майкоп: Адыгейский государственный университет, 2010. Вып. 4. С. 65-69.

12. Жандарова А.В, Семенова С.Н., Аксютенкова Л.Г. Современные проблемы когнитивной деятельности в предметной области «Предпринимательство и бизнес». Краснодар: Экоинвест, 2018. 
13. Mak W.M., Tribushinina E., Andreiushina E. Semantics of Connectives Guides Referential Expectations in Discourse: an Eye-Tracking Study of Dutch and Russian // Discourse Processes. The USA: Ablex Pub. Corp. 2013. Vol. 50. no 8. Pp. 557—576. doi: 10.1080/ $0163853 x .2013 .841075$.

14. Баранов А.Г. Когнитивные формализмы текстовой деятельности // Вестник Пятигорского лингвистического университета. Пятигорск: Пятигорский лингвистический университет. 1999. по 2. С. $34-37$.

15. Воркачев С.Г. Методологические основания лингвоконцептологии // Аспекты метакоммуникативной деятельности. Межвуз. сб. науч. тр. Воронеж, 2002. Вып. 3. С. 79—96.

16. Карасик В.И. Языковой круг: личность, концепт, дискурс. Волгоград: Перемена, 2002.

17. Батлер Б., Айзек А. Финансы: Толковый словарь. М.: Инфра-М Изд-во «Весь Мир», 2000. C. $5-455$.

\section{Information about the authors:}

Sofiya N. Semenova, candidate of Philology, Associate Professor of English in professional sphere department of Roman-German Philology Faculty at the Kuban State University; scientific interests: sociolinguistics, theory of discourse, semantics; e-mail: sofiya.semenova75@yandex.ru.

Lyudmila G. Aksyutenkova, candidate of Philology, Associate Professor of English in professional sphere department of Roman-German Philology Faculty at the Kuban State University; scientific interests: theory of language, terminology, morphology of terms; e-mail: ludmila100@mail.ru.

\section{Сведения об авторах:}

Семенова София Новиковна, кандидат филологических наук, доцент кафедры английского языка в профессиональной сфере факультета романо-германской филологии Кубанского государственного университета; научные интересы: социолингвистика, теория дискурса, семантика; e-mail: sofiya.semenova75@yandex.ru.

Аксютенкова Людмила Геннадьевна, кандидат филологических наук, доцент кафедры английского языка в профессиональной сфере факультета романо-германской филологии Кубанского государственного университета; научные интересы: теория языка, терминология, морфология терминов; e-mail: ludmila100@mail.ru. 